\title{
ANATOMY OF ECHINODORUS ( ALISMATACEAE) SCAPES FROM NORTHEASTERN BRAZIL AS APPLIED TO TAXONOMY
}

\author{
L. Q. Matias ${ }^{1}, A \cdot \operatorname{Soares}^{1} \&$ V. L. Scatena ${ }^{2}$
}

The anatomical characters of the scape of Echinodorus glandulosus, E. lanceolatus, E. palaefolius, E. paniculatus, E. pubescens and E. subalatus subsp. subalatus (Alismataceae) were examined. These six sympatric species occur in northeastern Brazil and demonstrate great morphological similarity. The aim of the present study was to identify anatomical characters of taxonomic importance. Scapes possess a uniseriate epidermis composed of thin-walled tabular cells. The scapes of most species have differentiated epidermis, cortex, and vascular cylinders. There are several layers of regular chlorenchyma cells immediately below the epidermis, intercalated with collateral vascular bundles, in all species. There are also laticiferous ducts throughout the scape, and aerenchyma in both the cortex and pith. The shape and outline of scapes, the presence and position of winged extensions, the absence of differentiated vascular cylinders or cortex, and the number of vascular bundles are important characters for differentiating species in Echinodorus. An identification key employing the features analysed is provided.

Keywords. Alismataceae, aquatic plants, Echinodorus, scape anatomy.

\section{INTRODUCTION}

Species of Alismataceae are either floating or emergent aquatic plants. The family comprises 12 genera and about 80 species from temperate and tropical regions (Haynes et al., 1998). Echinodorus Rich. ex Engelm. and Sagittaria L. are the only neotropical genera with significant species diversity (Fasset, 1955; Rogers, 1983). Echinodorus has 26 species (Haynes et al., 1998). They are common in tropical areas of South America, and this region is considered a primary centre of diversity for this genus (Lot \& Novelo, 1984; Haynes \& Holm-Nielsen, 1989).

Populations of Echinodorus are frequent in temporary lakes in northeastern Brazil, but species determination is difficult due to the high morphological similarity observed in sympatric populations. Additionally, there is little information concerning the biology of aquatic plants in ephemeral aquatic systems in this semiarid region, and the analysis of the internal structure of these plants should aid in our

\footnotetext{
${ }^{1}$ Universidade Federal do Ceará, Departamento de Biologia, Campus do PiCi, Bloco 906, 60451-760, Fortaleza, CE, Brazil. E-mail for correspondence: lqmatias@ufc.br

2 Departamento de Botânica, Instituto de Biociências, UNESP, C. Postal 199, 13506-900, Rio Claro, SP, Brazil. Bolsista CNPq.
} 
understanding of adaptive strategies for the environmental extremes common in those ecosystems: drought and flooding.

Stant (1964) and Tomlinson (1982) were the first investigators to describe anatomical features applicable to the taxonomy of Alismataceae. Guimarães (1999) examined the internal structure of leaves of Alismataceae species from Brazilian swamplands and concluded that aspects of the foliar anatomy were useful in the identification of species of Sagittaria. On the other hand, the author concluded that those same features were not useful for separating species of the genus Echinodorus.

The present work is based on an examination of the internal anatomy of Echinodorus. The authors examined scapes of the most common species of Echinodorus from the semiarid region of northeastern Brazil and identified characters that add to our taxonomic knowledge of this genus.

\section{Materials AND Methods}

The anatomical structure of Echinodorus glandulosus Rataj, E. lanceolatus Rataj, E. palaefolius (Nees \& Mart.) J.F.Macbr., E. paniculatus Micheli, E. pubescens (Mart.) Seub. ex Warm. and E. subalatus (Mart.) Griseb. subsp. subalatus, all from northeastern Brazil, was analysed. Reference specimens were deposited in the Herbário Prisco Bezerra (EAC) and in the Herbário do Instituto de Ciências Naturais (ICN). Specimens analysed are listed below.

Echinodorus glandulosus - Brazil: Ceará: Antonina, 18 v 2003, L.Q. Matias 421 (EAC, ICN).

Echinodorus lanceolatus - Brazil: Ceará: Granja, 17 vii 2003, L.Q. Matias 482 (EAC, ICN).

Echinodorus palaefolius - Brazil: Ceará: Crato, 16 v 2003, L.Q. Matias 418 (EAC).

Echinodorus paniculatus - Brazil: Bahia: Iraquara, 13 v 2003, L.Q. Matias 407 (EAC, ICN).

Echinodorus pubescens - Brazil: Ceará: Crateus, estrada para Serra das Almas, 25 vi 2003, L. Q. Matias 461 (EAC).

Echinodorus subalatus subsp. subalatus - Brazil: Ceará: Aiuaba, Estação Ecológica, Poço da Roça, 26 vi 2003, L.Q. Matias 469 (EAC, ICN); Paraíba: Brejo do Cruz, estrada para Catolé do Rocha, 20 iv 2003, L. Q. Matias 329 (EAC, ICN).

\section{Preparation of scape sections}

Fragments were taken from the distal region of the scape, $2 \mathrm{~cm}$ from its point of ramification. Fragments were fixed in 50\% FAA (Johansen, 1940), washed in 50\% ethanol and stored in 70\% ethanol.

The scape fragments were embedded in Jung historesin (Feder \& O'Brien, 1968). Blocks containing the scape fragments were then mounted on supports and sectioned 


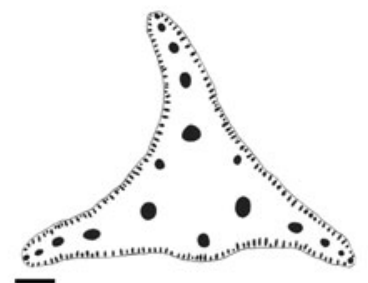

(1)
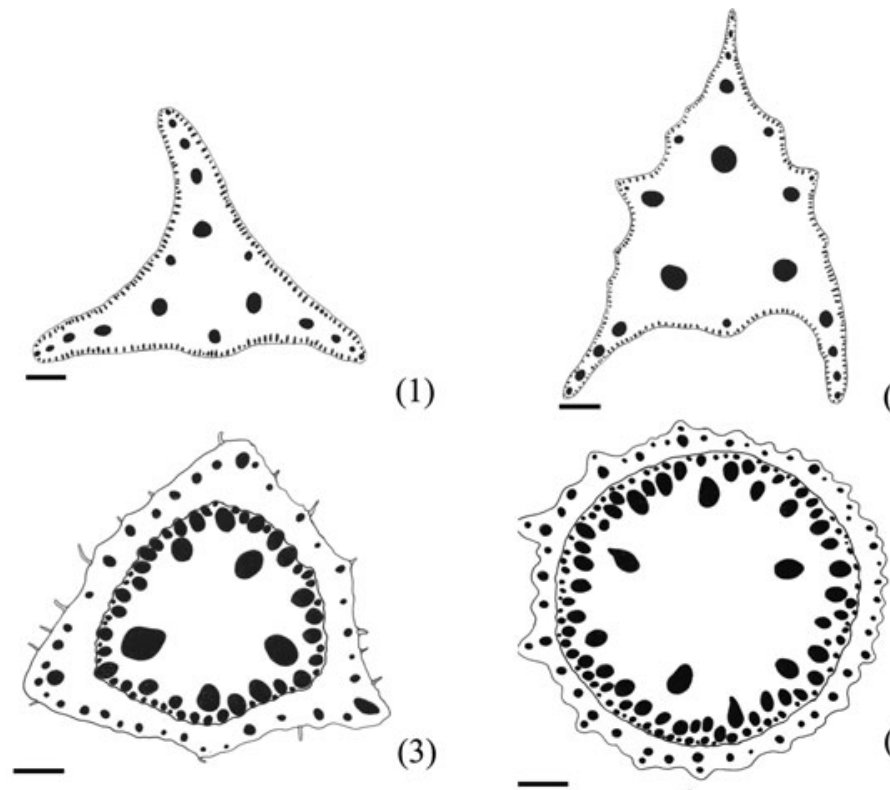

(4)

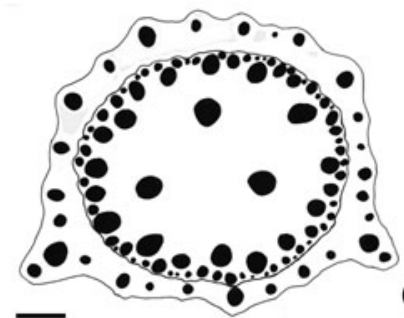

(5)
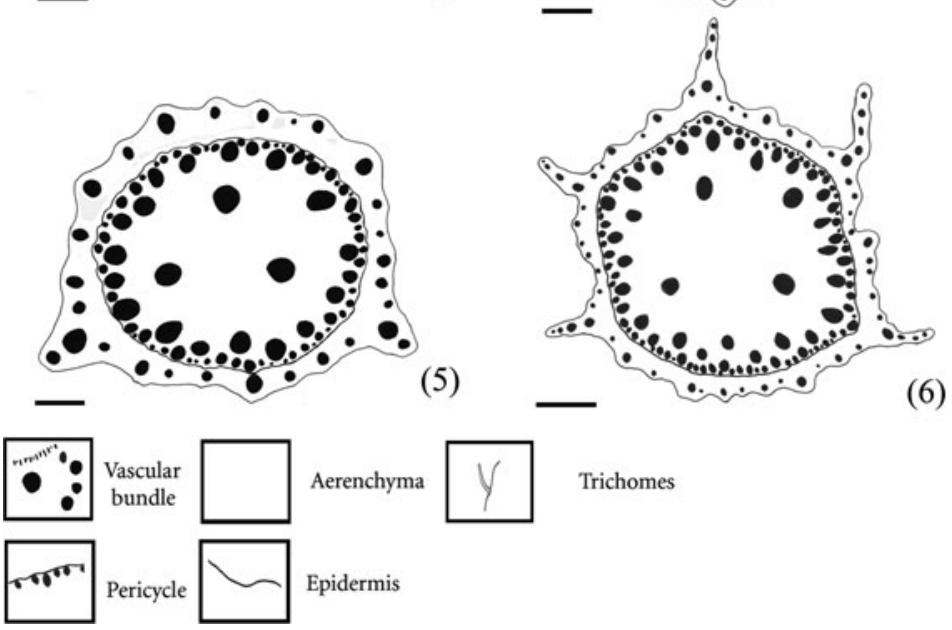

Trichomes

Figs 1-6. Diagrams of transverse sections of scapes of Echinodorus. 1, E. paniculatus $($ bar $=1.2 \mathrm{~mm}) ; 2$, E. lanceolatus $($ bar $=1.2 \mathrm{~mm}) ; 3$, E. pubescens $($ bar $=0.63 \mathrm{~mm})$; 4, E. glandulosus $($ bar $=1.15 \mathrm{~mm}) ; 5$, E. subalatus subsp. subalatus $($ bar $=0.63 \mathrm{~mm}) ; 6$, E. palaefolius (bar $=1 \mathrm{~mm})$.

with a Leica 2065 microtome at $5 \mu \mathrm{m}$. The transverse sections were stained with $0.12 \%$ toluidine blue (UETEC, Rio de Janeiro) in borax, and $0.05 \%$ aqueous basic fuchsin (Synth, São Paulo) (Junqueira, 1990), and mounted in Entellan (Merck, Darmstadt). Observations, interpretations and drawings were performed using an optical microscope (Dialux 20EB) with a camera lucida attachment. Micrometric scales were projected under the same optical conditions. 


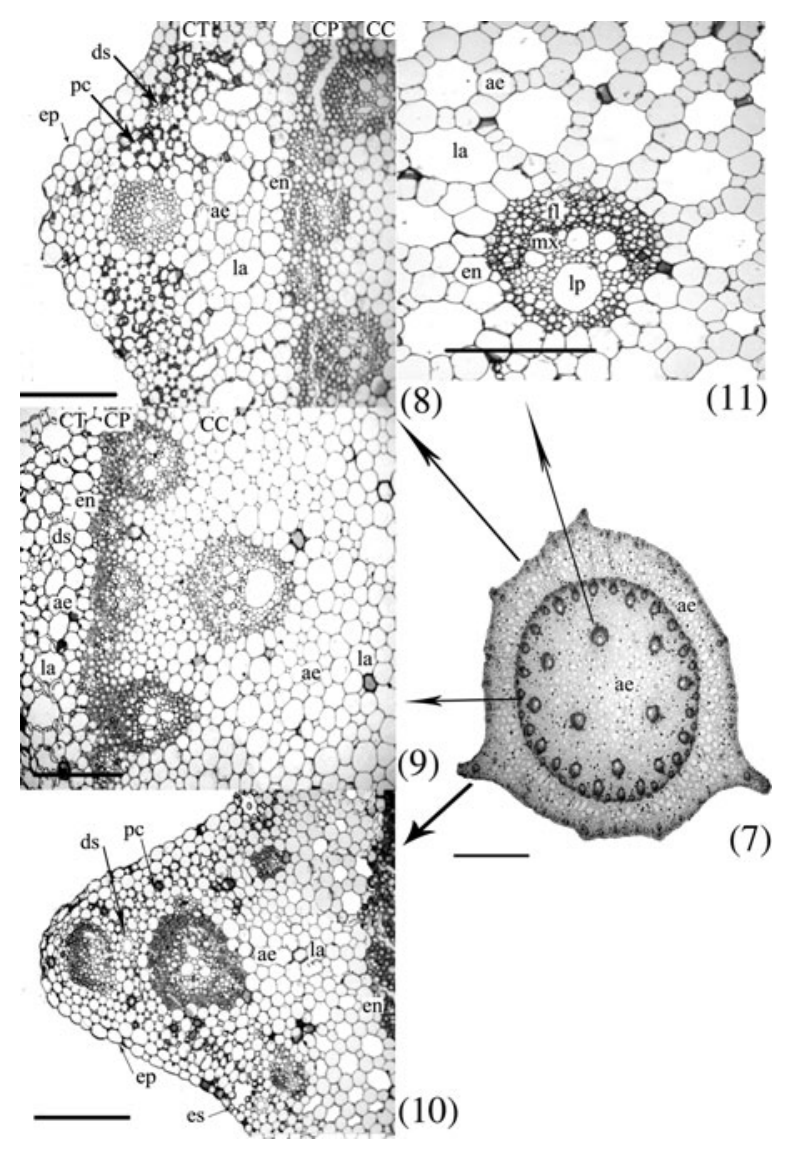

FIGS 7-11. Transverse section of the scape of Echinodorus subalatus subsp. subalatus. 7, general view of the section with the aerenchyma present in deeper layers of the cortex, the central cylinder, and inside the pith (bar $=1.2 \mathrm{~mm}$ ); 8 , detail of epidermis, cortex, and part of vascular cylinder $($ bar $=260 \mu \mathrm{m}) ; 9$, detail of cortex $($ bar $=260 \mu \mathrm{m}) ; 10$, detail of winged expansions $(\mathrm{bar}=260 \mu \mathrm{m}) ; 11$, detail of vascular bundle of the pith $(\mathrm{bar}=130 \mu \mathrm{m})$. ae, aerenchyma; CC, central cylinder; CT, cortex; CP, pericycle; ds, secretory ducts; en, endoderm; ep, epidermis; fl, phloem; la, lacuna of aerenchyma; lp, lacuna of protoxylem; $\mathrm{mx}$, metaxylem; pc, chlorenchyma.

\section{RESULTS}

In transverse section the scapes of Echinodorus (Figs 1-6) have a triangular form with three winged expansions in E. paniculatus and E. lanceolatus (Figs 1, 2, respectively); a triangular form in E. pubescens (Fig. 3); a circular outline in E. glandulosus (Fig. 4); an oblate form in E. subalatus subsp. subalatus (Fig. 5); and a pentagonal form with five winged expansions in E. palaefolius (Fig. 6). The surface is ribbed in all species; it is pubescent in Echinodorus pubescens; glabrescent in E. subalatus subsp. subalatus and E. palaefolius; and glabrous in E. glandulosus, 


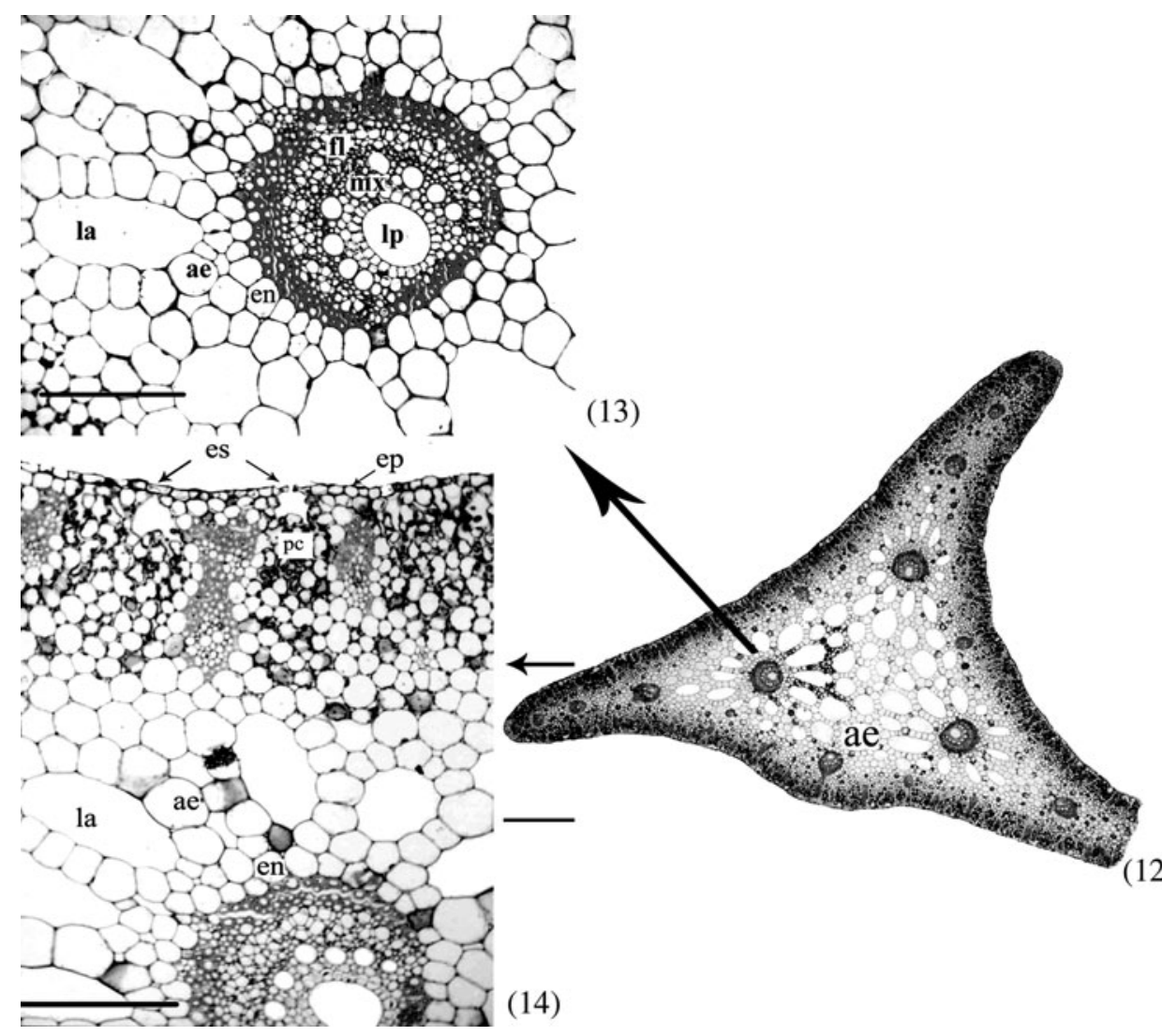

FIGS 12-14. Transverse section of the scape of Echinodorus paniculatus. 12, general view of the section with the aerenchyma and the larger lacunae within the deeper layers of the scape (bar $=1 \mathrm{~mm}) ; 13$, detail of vascular bundles from the central region $($ bar $=260 \mu \mathrm{m}) ; 14$, detail of the edge (bar $=260 \mu \mathrm{m}$ ). ae, aerenchyma; en, endoderm; ep, epidermis; es, stomata; $\mathrm{fl}$, phloem; la, lacuna of aerenchyma; lp, lacuna of protoxylem; mx, metaxylem; pc, chlorenchyma.

E. paniculatus and E. lanceolatus. Although the scapes have similar shapes in Echinodorus paniculatus and E. lanceolatus, the surface outline is concave in the former, and wavy and convex in the latter.

Most species show a distinct epidermis, cortex, and vascular cylinder (Figs 3-6), except for Echinodorus paniculatus and E. lanceolatus which have vascular bundles dispersed in the cortical parenchyma without the formation of a pericycle (Figs 1,2). Species with a delimited vascular cylinder with a pericycle have most cortical vascular bundles situated at the periphery of the cortex (Figs 3-6, 8, 9).

In species that have winged expansions, these winged expansions can be either short, as in Echinodorus subalatus subsp. subalatus (Fig. 5), or long, as in 
E. paniculatus (Fig. 1), E. lanceolatus (Fig. 2) and E. palaefolius (Fig. 6). In Echinodorus subalatus subsp. subalatus both of the winged expansions have two vascular bundles (Fig. 5), whereas E. paniculatus and E. lanceolatus have four vascular bundles in each winged expansion (Figs 1, 2, respectively). Echinodorus palaefolius (Fig. 6) has four or five vascular bundles in each winged expansion.

The epidermis (in transverse section) of all species has fairly rounded to thinwalled tabular cells (Figs 8, 10). The guard cells are located at the same height as the other epidermal cells (Figs 10, 14).

The stomata cells are located at the same level as the other epidermal cells. Stomata are distributed among the vascular bundles between the chlorenchyma which is situated immediately under the epidermis (Figs 10, 14). Laticiferous ducts are present in both the cortex (Figs 8, 10) and the vascular cylinder (Fig. 9).

The collateral vascular bundles in the scapes vary in size. The smallest ones are located at the periphery of the cortex and vascular cylinder (if they are distinct), while the largest ones occupy a more central position (Figs 1-6, 7, 12).

In Echinodorus subalatus subsp. subalatus, E. palaefolius, E. pubescens and E. glandulosus the vascular bundles occur in a position further from the epidermis, under three to five layers of chlorenchyma (Figs 8, 9). On the other hand, in Echinodorus lanceolatus and E. paniculatus, the vascular bundles occur immediately under the epidermis and beneath only one layer of chlorenchyma cells (Fig. 14).

In Echinodorus subalatus subsp. subalatus, E. palaefolius, E. pubescens and E. glandulosus, aerenchyma is found in the inner layers of the cortex, in the vascular cylinder, and in the pith (as can be seen in E. subalatus, Fig. 11). Among the species listed above as having a distinct vascular cylinder, the lacunae formed by the aerenchyma are smaller than the lacunae of aerenchyma present in the central region of Echinodorus lanceolatus and E. paniculatus (Fig. 12).

In species having a pericycle, this is located immediately to the inside of the endodermis. Cylinder-like collateral vascular bundles of alternating sizes are distributed between thick-walled pericycle cells forming a mechanical tissue which internally limits the vascular cylinder (Figs 8, 9).

All vascular bundles are collateral and surrounded by a continuous endodermis (external sheath) and pericycle (internal sheath), which may occur in more than one layer (Figs 11, 13). The largest vascular bundles are deeper within the vascular cylinder and have a large lacuna of protoxylem (Figs 7, 12).

Some of the anatomical characteristics of the scapes used in the taxonomic identification key are presented in Table 1.

\section{Key to Echinodorus species from northeastern Brazil based on scape anatomical characteristics}

1a. Scape with a distinct cortex and central cylinder

1b. Scape not having a distinct central cylinder 
TABLE 1. Anatomical characters of the scapes of Echinodorus

\begin{tabular}{|c|c|c|c|c|c|c|}
\hline Characters & E. glandulosus & E. lanceolatus & E. palaefolius & E. paniculatus & E. pubescens & $\begin{array}{l}\text { E. subalatus } \\
\text { subsp. subalatus }\end{array}$ \\
\hline Transverse section shape & Circular & Triangular & Pentagonal & Triangular & Triangular & Oblate \\
\hline Surface outline & $\begin{array}{l}\text { Convex with } \\
\text { excrescences }\end{array}$ & $\begin{array}{l}\text { Convex with } \\
\text { excrescences }\end{array}$ & $\begin{array}{l}\text { Flat to convex } \\
\quad \text { with excrescences }\end{array}$ & $\begin{array}{l}\text { Concave without } \\
\text { excrescences }\end{array}$ & $\begin{array}{l}\text { Convex with } \\
\text { excrescences }\end{array}$ & $\begin{array}{l}\text { Convex with } \\
\text { excrescences }\end{array}$ \\
\hline Winged expansions & Absent & Present & Present & Present & Absent & Present \\
\hline $\begin{array}{l}\text { Position of winged } \\
\text { expansions }\end{array}$ & - & Angular & Angular & Angular & - & Dorsilateral \\
\hline $\begin{array}{l}\text { Number of vascular } \\
\text { bundles on winged } \\
\text { expansions }\end{array}$ & - & 4 & 4 or 5 & 4 & - & 2 \\
\hline Indumentum & Glabrous & Glabrous & $\begin{array}{l}\text { Glabrescent to } \\
\text { glabrous }\end{array}$ & Glabrous & Pubescent & $\begin{array}{l}\text { Glabrescent to } \\
\text { glabrous }\end{array}$ \\
\hline Pericyclical bundles & Present & Absent & Present & Absent & Absent & Present \\
\hline
\end{tabular}


2a. Winged expansions present 3

2b. Winged expansions absent 4

3a. Scape in transverse section oblate, with two latero-dorsal winged expansions of equal size E. subalatus subsp. subalatus

3b. Scape in transverse section pentagonal, winged expansions three to five, angular, of different sizes E. palaefolius

4a. Surface glabrous, transverse section circular E. glandulosus

4b. Surface pubescent, transverse section triangular E. pubescens

5a. Surface outline of scape concave, with no excrescences E. paniculatus 5b. Surface outline of scape convex, with excrescences E. lanceolatus

\section{DISCUSSION}

The scapes of the Echinodorus species studied are anatomically characterised by: the presence and number of winged expansions; the presence of thin-walled epidermal cells, with stomata situated at the same level as other epidermal cells; the presence of aerenchyma; the occurrence of laticiferous ducts along their length; the number of vascular bundles in the winged expansions, and the presence or absence of a pericycle. The information gathered contributes to a better characterisation of Echinodorus species from temporary lagoons in semiarid regions of Brazil. The data also contribute to our understanding of the adaptive strategies employed by aquatic plants subjected to extreme environmental conditions (inundation and drought). These species demonstrate characteristics of both aquatic angiosperms (such as thin-walled epidermal cells and the regular presence of aerenchyma) and terrestrial plants and xerophytes (such as the presence of latex and an abundance of vascular bundles; Fahn, 1990).

The occurrence of aerenchyma with ample aeriferous lacunae in the scapes may be associated with both floating and aeration, as was observed by Sifton (1945) in Nymphaeaceae. As such, this tissue enables buoyancy of the scapes and the emergence of inflorescences during inundation, as well as facilitating the diffusion of oxygen throughout the plant. The abundance of thick-walled pericycle cells is mostly likely related to support for the scapes and exposure of the inflorescence during periods with low water levels.

Another interesting feature is the presence of a great number of vascular bundles, usually more characteristic of xeromorphic plants (Fahn, 1990). This abundance of vascular bundles may be related to the need to supply the inflorescence with water as the dry season proceeds.

All species had latex-secreting ducts in the scape. The presence of these structures is a form of specialisation and was considered an autopomorphic characteristic of Alismataceae by Dahlgren \& Rasmussen (1983). Latex-secreting structures have also been found in other representatives of Alismatales (such as Lymnocharitaceae) but were placed in different anatomical categories by this same author (Dahlgren et al., 1985). However, the lack of ontogenetic studies means it is not possible to establish 
homology between latex-secreting structures among the different families of Alismatales (Tomlinson, 1982; Les \& Haynes, 1995).

The results of the present work demonstrate that anatomical characters are easily observed under optical microscopy and are important in the identification of the species studied.

Tomlinson (1982) observed two distinct patterns of scape anatomical structure in Alismataceae, and associated them with the presence or absence of a central vascular cylinder. Among species with a vascular cylinder, those belonging to the genera Baldellia Parl. and Damasonium Mill. have a pattern that is similar to that described for Echinodorus subalatus subsp. subalatus, E. palaefolius, E. pubescens and E. glandulosus in the present work. However, Tomlinson (1982) did not note the presence of an endodermis in the material analysed, reporting only the existence of a mechanical tissue composed of fibres between the cortex and the central cylinder. An endodermis was observed, however, in the leaf of Echinodorus paniculatus (Menezes et al., 2005). The endodermis observed in the scapes of Echinodorus species in this study occupies the same position as that indicated by Menezes et al. (2005).

Echinodorus lanceolatus and E. paniculatus have no pericycle. There is also no pericycle present in species of the genera Sagittaria, Limnophyton Miq. and Wiesneria Micheli (Alismataceae) (Stant, 1964). Thus, there is a similarity in the pattern of the scape inner structure among those species. Additionally, the anatomical structures of the scapes of Echinodorus lanceolatus, E. paniculatus and representatives of Wiesneria are similar to those seen in the petiole (Stant, 1964; Tomlinson, 1982; Matias et al., 2007).

On the other hand, scapes with differentiated vascular cylinders were observed in species of Alisma L., Baldellia and Damasonium, as well as in Echinodorus subalatus subsp. subalatus, E. palaefolius, E. pubescens and E. glandulosus, with a similar scape structure seen in the two groups of Alismataceae. However, representatives of the genera Alisma, Baldellia and Damasonium have scapes with a central fistulum surrounded by parenchyma cells, as well as vascular bundles between the vascular cylinder and the cortex.

The characters analysed in this work, such as whether the scapes have a triangular or circular form in transverse section, the regular chlorenchyma in the outer portion of the cortex, the presence of aerenchyma in the cortex as well as in the pith, the vascular bundles concentrically arranged, and the presence of laticiferous ducts, are similar to characters known to have taxonomic importance in other genera of Alismataceae (see Stant, 1964). The winged expansions are an exception, being features not recorded for other genera of this family.

Species can be differentiated by their scape profiles in transverse section. The outline shape of scapes distinguishes Echinodorus paniculatus from E. lanceolatus. Similarly, the positions of the winged expansions are important in differentiating Echinodorus palaefolius and E. subalatus.

The use of anatomical characters for taxonomic purposes can aid in the identification of fragmented samples, as well as material stored in herbaria. These 
characters can also provide information concerning interrelationships between taxa at both specific and supraspecific levels (Metcalfe, 1968). This has been shown to be important in other groups of monocotyledons, such as Heliconia L. (Heliconiaceae), where characters such as the distribution of fibre bundles in the abaxial region and the size of air canals in the mesophyll associated with the shape of bracts were important to define variation among the subgenera (Simão \& Scatena, 2004).

\section{ACKNOWLEDGEMENTS}

We thank the Universidade Federal do Rio Grande do Sul, Botany Post Graduate Program, O Boticário Foundation and the PIDCT/CAPES program for their financial support of this project.

\section{REFERENCES}

Dahlgren, R. M. T. \& Rasmussen, F. N. (1983). Monocotyledon evolution: characters and phylogenetic estimation. Evol. Biol. 16: 255-395.

Dahlgren, R. M. T., Clifford, H. T. \& Yeo, P. F. (1985). The Families of the Monocotyledons. Berlin: Springer-Verlag.

Fahn, A. (1990). Plant Anatomy, 4th edition. Oxford/London: Pergamon Press.

Fasset, N. C. (1955). Echinodorus in the American tropics. Rhodora 57: 133-156, 174-188, 202-212.

FEDER, N. \& O'BRIEN, T. P. (1968). Plant microtechnique: some principles and methods. Amer. J. Bot. 55: 123-142.

Guimarães, E. S. (1999). Alismataceae da região sul do Pantanal Mato-Grossense. MSc thesis (unpublished), Universidade de São Paulo, Brazil.

Haynes, R. R. \& Holm-Nielsen, L. B. (1989). Speciation of Alismatidae in the Neotropics. In: Holm-Nielsen, L., Nielsen, I. C. \& Balslev, H. (eds) Tropical Forests: Botanical Dynamics, Speciation and Diversity, pp. 211-219. London: Academic Press.

Haynes, R. R., Les, D. H. \& Holm-Nielsen, L. B. (1998). Alismataceae. In: K uвiтzк I, K. (ed.) The Families and Genera of Vascular Plants. Vol. IV-Flowering plants, monocotyledons: Alismatanae and Commelinanae (except Graminae), pp. 11-15. Berlin: Springer-Verlag.

Johansen, D. (1940). Plant Microtechnique. New York: McGraw-Hill.

Junqueira, C. V. (1990). O uso de cortes finos de tecidos na medicina e biologia. Meios e Métodos 66: 10-11.

Les, D. H. \& Haynes, R. R. (1995). Systematics of subclass Alismatidae: a synthesis of approaches. In: Rudall, P. J., Cribi, P. J., Cutler, D. F. \& Humphries, C. J. (eds) Monocotyledons: Systematics and Evolution, pp. 353-377. Kew: Royal Botanic Gardens.

Lot, A. \& Novelo, A. (1984). Afinidades floristicas de las monocotiledoneas acuaticas mesoamericas. In: DAR win, S. P. \& WELdEN, A. L. (eds) Biogeography of Mesoamerica. Proceedings of a Symposium, pp. 147-153. New Orleans: Tulane University.

Matias, L. Q., Soares, A. \& Scatena, V. L. (2007). Systematic consideration of petiole anatomy of species of Echinodorus Richard (Alismataceae) from north-eastern Brazil. Flora 202: 395-402.

Menezes, N. L. De, Silva, D. C., Arruda, R. C. O., Melo-De-Pinna, G. F., Cardoso, V. A., Castro, N. M., Scatena, V. L. \& Scremin-Dias, E. (2005). 
Meristematic activity of the endodermis and the pericycle in the primary thickening in monocotyledons. Consideration on the "PTM". Anais Acad. Brasil. Ci. 77(2): 259-274.

Metcalfe, C. R. (1968). Current concepts in systematic plant anatomy. In: Heywood, V. H. (ed.) Modern Methods in Plant Taxonomy, pp. 146-150. London: Academic Press.

Rogers, G. K. (1983). The genera of Alismataceae in the Southeastern United States. J. Arnold Arbor. 64: 383-420.

Sifton, H. B. (1945). Air-space tissue in plants. Bot. Rev. 11: 108-143.

Simão, D. G. \& Scatena, V. L. (2004). Morfoanatomia das brácteas em Heliconia (Heliconiaceae) ocorrentes no Estado de São Paulo, Brasil. Acta Bot. Brasil. 18(2): 261-270.

Stant, M. Y. (1964). Anatomy of the Alismataceae. J. Linn. Soc., Bot. 59: 1-42.

Tomlinson, P. B. (1982). VIII. Helobiae (Alismatidae). In: Metcalfe, C. R. (ed.) Anatomy of Monocotyledons, vol. 2, pp. 57-81. Oxford: Clarendon Press.

Received 29 May 2007; accepted for publication 16 October 2007 